\title{
PENEMPATAN SDM PENYANDANG DISABILITAS DI SEKTOR PARIWISATA
}

\author{
Titing Kartika \\ Universitas Pendidikan Indonesia, Bandung Indonesia \\ Email: titingkartika@upi.edu,nengtiting_kartika@yahoo.co.id \\ Tjutju Yuniarsih \\ Universitas Pendidikan Indonesia, Bandung Indonesia \\ Email: yuniarsih@upi.edu \\ Hady Siti Hadijah \\ Universitas Pendidikan Indonesia, Bandung Indonesia \\ Email: hady@upi.edu
}

\begin{abstract}
The existence of a negative stigma in society's view for persons with disabilities makes them unable to show their optimal self-existence even though they competently have them. Not all industries or government agencies have implemented the rules whereby the agencies they manage should implement rules for employing persons with disabilities (the proportion is private sector $1 \%$, and government agencies $2 \%$ ) referring to the rules mandated in Law no. 8 of 2016 concerning Persons with Disabilities. According to the perspective of Human Resources management, this is a challenge how the existence of persons with disabilities can get space without discrimination from all parties. The resultsof research showed that the inoptimal placement of human resources with disabilities occurred due to several factors, both from the person and the employer. The involvement of stakeholders has an important role in solving problems from associations, universities, communities and the government.
\end{abstract}

Keywords: Disabilities, Human Resources, Tourism Sector, Employee Placement

\section{Pendahuluan}

SDM (Sumber Daya Manusia) adalah bagian penting dalam pengelolaan sebuah usaha atau bisnis. Dalam kenyataannya, ketersediaan SDM dihadapkan dalam berbagai kondisi diantaranya SDM yang mengalami keterbatasan. Keterbatasan yang 
dimaksud dalam hal ini adalah penyandang disabilitas. Hal ini tercantum dalam Undang-Undang Republik Indonesia Nomor 8 Tahun 2016 mengenai persamaan hak kaum disabilitas dalam mendapatkan hak di berbagai bidang.

Penguatan lain mengenai persamaan dalam memiliki kesempatan bekerja adalah tertuang dalam Undang-Undang Dasar 1945 Pasal 27. Namun demikian dalam implementasinya masih banyak yan terjadi yang tidak menunjukkan ketidaksesuain dengan aturan yang telah ditentukan. Seperti yang diungkapkan oleh Rozali, dkk (2017) bahwa hak mendapatkan pekerjaan adalah untuk setiap orang termasuk bagi pengyandang disabilitas. Hal ini sama pentingnya dengan kebutuhan dasar laiinnya yang seharusnya terpenuhin oleh setiap warga seperi dalam bidang kesehajteraan dan kenyamanan serta pendidikan. Lebih jauh kondisi yang memprihatinkan adalah adanya diskrimasi yang tak dapat dihindarkan sehingga hal ini menjadi tantangan tersendiri. Kondisi tergambarkan menurut laporan dari United Nations-ESCAP (2019).

Sektor pariwisata menjadi slah satu bagian penting dalam pembangunan nasioal dan memiliki kontribusi dalam penyerapan tenaga kerja. Berbagai kondisi yang menunjukkan penempatan masyarakat disabilitas dalam kondisi yang tidak sesuai dengan prinsip-prinsip peraturan perundang-undangan yang berlaku, menjadikan salah satu alasan penulis untuk melakukan kajian lebih dalam akan permasalahan yang terjadi.

\section{Metode Penelitian}

Penelitian ini didasarkan pada pendekatan kualitatif deskriptif dengan memfokuskan pada analisis terhadap kondisi yang ada dan konten terkait kebijakan. Sementara itu proses pengumpulan data melalui hasil kajian literatur berkenaan dengan permasalahan yang terjadi terutama penempatan SDM penyandang disabilitas di sektor pariwisata khsususnya di hotel. Dalam proses pengumpulan data, 
dokumen yang digunakan meliputi hasil penelitian sebelumnya seperti jurnal dan kajian ilmiah lainnya, peraturan perundang-undangan yang ada di Indonesia dan terkait dengan kajian yang diteliti, serta dokumen pendukung lainnya.

Untuk penguatan data, penulis melakukan wawancara kepada pihak terkait yaitu kepada: Senior Employment Service Officer, Direktorat Penempatan Tenaga Kerja Dalam Negeri, Kementerian Ketenagakerjaan, Republik Indonesia, Anggota Asosiasi PHRI (Perhimpunan Persatuan Hotel dna Restoran Indonesia), dan Pelaku usaha di bidang Perhotelan.

\section{Kerangka Teori Atau Konsep}

\section{SDM dan Disabilitas}

Terdapat beberapa pemahaman mengenai Sumber Daya Manusia (SDM) dari bebagai kajian. Salah satunya adalah Yniarsih (2018) mengungkapkan bahwa keberadaan SDM adalah hal yang sangat penting untuk keberlangsungan suatu organisai baik yang bersifat profit maupun non-profit. Dalam implementasinya SDM memiliki 9 (Sembilan) cakupan strategi yang terintegrasi seperti yang dijelaskan oleh Millmore dkk (2017) yaitu mencakup pekerjaan atau desain kerja, perencanaan sumber daya manusia, rekrutmen dan seleksi, manajemen kinerja, pengembangan sumber daya manusia, manajemen penghargaan, hubungan karyawan, perampingan, dan keterlibatan karyawan. Cakupan tersebut memiliki hubungan satu sama lain untuk membangun organisasi yang harmonis.

Pada kenyataanya suatu organisasi atau perusahaan dihadapkan pada penyediaan SDM dengan kapasitas yang tidak sama. Keanekaragam tersebut salah satunya adalah terkait dengan kondidi fisik seseorang yang akan bekerja dan akan menjadi pertimbangan sebelum memperkerjakannya. Pada prinsipnya tidak boleh 
ada pembedaan perlakuan kepada manusia berdasarkan apapun baik itu suku, ras, maupun perbedaan kondisi fisik seseorang.

Terdapat beberapa definisi mengenai penyandang disabilitas mengacu kepada perUndang-Undangan yang ada. Penyandang Disabilitas adalah setiap orang yang mengalami keterbatasan fisik, intelektual, mental, dan/atau sensorik dalam jangka waktu lama yang dalam berinteraksi dengan lingkungan dapat mengalami hambatan dan kesulitan untuk berpartisipasi secara penuh dan efektif dengan warga negara lainnya berdasarkan kesamaan hak (UU RI Nomor 8 Tahun 2016). Sementara itu jenisnya mencakup penyandang disabilitas fisik, intelektual, mental dan sensorik. Perbedaan tersebut tentunya berpengaruh pada pemebraian alat bantu, sarana maupun prasarana yang diberika oleh masing-masing pemebri kerja agar dapat membantu selama proses melakukan pekerjaan.

International Labour Organization (ILO) 2013, telah mengatur mengenai pengelolaan disabilitas dimana proses penempatan merupakan bagian yang sangat penting. Tahapan-tahapan yang harus dilalaui sebelum penempatan adalah proses rekruitmen yang meliputi tahap persiapan, wawancara tes, proses orientasi pekerjaan, pengalaman kerja, tahap percobaan serta penempatan. Pada penempatan ini dilihat berdasarkan tinjauan kemajuan dari masing-masing calon pekerja.

Pengaturan lain dalam memperkerjakan penyandang disabilitas aadalah pada aspek promosi, jaminan tetap bekerja dan beberapa penyesuaian baik aksesibilitas, adaptasi dan insentif. Pengaturan ini sangat penting untuk menghindari diskriminasi. Dalam konteks ini, diskriminasi yang dimaksud adalah adanya sikap yang membedakan, mengucilkan berdasarkan alasan-alasan tertentu yang dapat mengakibatkan adanya pengurangan kesetaraan baik dalam kesempatan maupun perlakuan di tempat kerja. 
Terdapat hasil penelitian sebelumnya yang dilakukan oleh Aji dan Haryani (2017) yaitu (a) masih terdapat tantangan sosial sebagai salah satu penghambat dalam proses kesetaraan disabilitas dalam mendapatkan kesempatan kerja, (b). Adanya aturan perundang-undangan pada prinsipnya memberikan peluang kesetaraan, namun implemtasinya masih tedapat beberapa kendala, (c) adanya implikasi bahwa adanya pemenuhan hak kaum disbailitas dari penyedia lapangan kerja. Kondisi ini tentu tidak mudah karena harus melibatkan berbagai pihak dari dua sisi baik pencari kerja (kaum disabilitas) maupun penyedia kerja.

\section{Kebutuhan SDM Pariwisata}

Pariwisata merupakan sumber utama lapangan kerja karena sifatnya yang luas dan memberikan dampak berganda (multiflier effect) yang signifikan terhadap lapangan kerja di sektor terkait. Pada tahun 2015, perjalanan dan pariwisata secara keseluruhan (langsung dan tidak langsung) menghasilkan 284 juta pekerjaan dan jumlah ini diharapkan mencapai 370 juta pada tahun 2026. Diperkirakan bahwa satu pekerjaan di sektor pariwisata inti menciptakan sekitar satu setengah pekerjaan tambahan atau tidak langsung. Pekerjaan dalam ekonomi terkait pariwisata, misalnya transportasi, penyediaan makanan dan minuman, kerajinan tangan, pelestarian aset budaya dan alam. Sektor pariwisata secara keseluruhan menyumbang satu dari 11 pekerjaan (langsung dan tidak langsung) di dunia (World Travel \&Tourism Council/WTTC, 2016).

Diperkirakan secara global terdapat lebih dari 250 jaringan hotel, dengan perusahaan terbesar termasuk portofolio masing-masing lebih dari 6.000 hotel dan mempekerjakan lebih dari 150.000 karyawan di hingga 100 negara. Subsektor hotel dan restoran dicirikan oleh keragaman dan fragmentasi dengan 20 per persen dari tenaga kerja yang bekerja di perusahaan multinasional dan 80 persen tenaga kerja hotel dan restoran yang berada di perusahaan kecil dan menengah/UKM (ILO, 2017). 
Berkaitan dengan penciptaan lapangan kerja, khususnya di industri perhotelan sebagai tempat masyarakat menghabiskan waktu tinggalnya dan menggunakan fasilitas, banyak dibutuhkan tenaga yang terampil dan kompeten. Namun, terdapat gap antara pekerja yang berkualitas dengan supply pekerja yang dapat memenuhinya. Mengacu pada data Badan Pusat Statistik Indonesia bahwa terjadi penurunan lapangan pekerjaan sebesar 5,5\% pada Fberuari 2016 yakni mencapai 7,02 juta jika dibandingkan dengan Februari 2015. Pada tahun 2015 mencapai 5,18\% atau mencapai sekitar 7,45 juta. Data lain menunjukkan dari aspek pendidikan di tingkat SD terjadi penurunan lulusan SD dari 3,61\% menjadi 3,44\%. Sementara itu, tingkat pengangguran lulusan SMK terjadi kenaikan yakni mencapai 9,84\%. Hal yang menjadi perhatian adalah adanya peningkatan pengangguaran lulusan Universiats menjdai 6,22\% dari tahun sebelumnya 5,34\%. Data ini memberikan gambaran bahwa masyarakat terpelajar juga mengalami kesulitan untuk memasuki pasar kerja dengan keterampilan yang tidak memadai dan kompetensi yang kurang.

Sementara itu, data dari Survei Sensus Nasional 2012, penyandang disabilitas yang bekerja di sektor kerja perdagangan, hotel dan restoran mencapai $0,015 \%$ atau 336.327 orang dari total 2.194 .331 orang. Pekerja penyandang disabilitas mayoritas bekerja di sektor pertanian, hortikultura, perikanan, perunggasan, dan sektor dan didominasi oleh lulusan sekolah dasar dengan kompetensi dan keterampilan yang rendah. Sehingga, masih minimnya kesempatan bagi penyandang disabilitas khususnya di bidang ketenagakerjaan. Berdasarkan kondisi tersebut, dalam Perpres Indonesia terdapat peraturan tentang Disabilitas yang tertuang dalam Peraturan Nasional Nomor 8 Tahun 2016 yang mewajibkan semua penyandang disabilitas mendapatkan hak yang sama untuk mendapatkan pekerjaan yang layak, artinya tidak boleh ada diskriminasi atau stigma yang menjadi hambatan. bagi para penyandang disabilitas (penyandang disabilitas) untuk mendapatkan pekerjaan di semua sektor, salah satunya industri perhotelan. 


\section{Kesempatan Penyandang Disabilitas}

Tidak ada yang mau dilahirkan dengan memiliki kekurangan baik fisik maupun non-fisik. Setiap manusia menginginkan hal yang layak bagi kehidupannya. Namun tidak semua orang dapat merasakan kelayakan hidup setiap saat.Tentunya hal ini menjadi tantangan tersendiri baik bagi pencari kerja maupun penyedia kerja.

Hambatan yang dirasakan oleh penyandang disabilitas diantaranya saat melakukan interaksi sosial di lingkungan kerja. Kesulitan lain yang mereka alami adalah dalam mengakses informasi, menggunaan teknologi serta aspek lainnya tergantung dari keterbatasan fisik apa yang mereka miliki. Dengan hambatan ini akhirnya berpengaruh terhadap proses pengembangan karir mereka jika tidak didukung oleh peralatan atau sarana bekerja. Dengan kata lain, penyandang disabilitas memiliki potensi yang sama dengan pekerja normal dalam menyalurkan potensi dan bakatnya.

Pengaturan mengenai pemenuhan hak bagi penyandang disabilitas sudah tercantum dalam Pasal 53 UU No. 8 Tahun 2016 tentang Penyandang Disabilitas. Dinyatakan bahwa adnaya kewajiban perusahaan untuk memberikan kesempatan kepada penyandang disabilitas di sektor swasta sebsesar $1 \%$ dan di sekor pemerintahan sebesar 2\%. Dalam kenyataanya masih banyak baik perusahaan pemerintah maupun swasta yang belum memenuhi persyaratan tersebut dikarenakan beberapa faktor.

Terdapat beberapa pengaturan mengenai kesempatan kerja bagi penyandang disabilitas di Indonesia. PerUndang-Undangan tersebut mecakup:

1. Undang-Undang Dasar Negara RI tahun 1945 Pasal 28/I ayat 2 mengenai keberhakkan seseorang untuk mendapatkan perlakukan bebas dari diksriminsai 
2. Undang-Undang Tahun 1997 No.4 Tentang Penyandang Cacat yang menekankan mengenai pemenuhan hak disbalitas dalam pekerjaan.

3. Undang-Undnag Thaun 2002 No,13 Tentang Ketenakerjaan menegnai kesmepatan yang sama bagi setiap pekerja tanpa diskriminasi

4. Undang-Undang Republik Indonesia Nomor 19 Tahun 2011 tentang pengesahan konvensi hak-hak penyandnag disabilitas.

Dengan adanya Undang-Undang tersebut menunjukkan bahwa adanya landasan hukum yang kuat dalam melindungi penyandang disabilitas dalam mendaptkan hak yang sama dalam mendapatkan pekerjaan serta bebas dari perlakuan diskriminasi.

Mengacu pada data Kementerian Sosial RI, jumlaj penyandang cacat terus meningkat. Kegiatan survey dilakukan pada 9 (sembilan) provinsi di Indonesia dengan hasilnya terdapat 10,5\% atau sekitar 31.327 jiwa dengan kategori cacat berat dari seluruh 299.203 orang. Cacat berat ini menghambat dalam kegiatan sehari-hari mereka sehingga tidak dapat melakukan kegiatan secara optimal. Sementara itu didaptkan data sekitar 67,33\% penyandang cacat yang tidak mempunyai ketermapilan. Pekerjaan yang dapat mereka lakukan sangat terbatas mencakup tukang pijat, petani, buruh jasa serta pertukangan.

Berdasarkan data jenis kelamin didapatkan data bahwa penyandang cacat lkilaki lebih tinggi jika dibandingkan dengan perempuan yakni jumlah penyandang cacat laki-laki mencapai 57,96\%. Jika dlihat dari sebaran Provinsi, provinsi yang paling rendah jumlah penyandang cacat berada di Provinsi Gorontalo yakni 1,65\$ dan teringgi berada di Provinsi Jawa Barat mencapai 50,90\%. Informasi lain adalah dari sisi rentang usia yang paling tinggi mengalami cact adalah pada usia 18-60 tahun. Jenis kecacatan yang dialami beragam yakni kesulitan bicara (13,08\%), mental retardasi (15, 41\%), serta cacat kaki mencapai 21,86\%. (www.kemsos.go.id). 
Penjabaran data tersebut memberikan informasi bahwa menjadi pemikiran bersama bagaimana berbagai pihak dalam mengoptimalkan peran penyandang disabilitas sehingga mereka tetap dapat mendapat perlakukan yang sesuai.

Penyandang disabilitas tak selamanya hanya dipandang dari sisi kekurangannya saja. Hasil beberapa penelitian menunjukkan banyak manfaat yang diperoleh ketika memperkerjakan penyandang disabilitas (Lindsya, et al, 2018) adalah mereka dalam kategori pekerja yang setia kepada perusahannya. Temuan lain adalah dari dari data Government of Western Australia Department of Communities Disability Services, sikap penyandang disabilitas menunjukkan sikap dan perilaku positif di lingkungan kerjanya. Sikap tersebut diantaranya:

1. Dari aspek produktifitas, penyandang disabilitas cenderung produktif sepanjang diberikan pekerjaan yang sesuai dan difaisilitasi dengan alat pendukung lainnya terkait dengan jneis disabilitas apa yang mereka miliki.

2. Dari sisi konsistensi kerja, penyandang disabilitas melaksanakan pekerjaan secara konsisten, lebih lama dapat berada di tempat kerja dibandingkan dnegan pekerja normal lainnya.

3. Dari sisi pembiayaan, proses rekrutmen bisa lebih murah jika dibandingkan dnegan merekruit pekerja yang normal.

4. Dari sisi keamanan, dari hasil penelitian menunjukkan bahwa penyandang disabilitas sedikit mengalami kecelakaan atau terluka pada saat melaksanakan pekerjaan.

5. Dari aspek membangun hubugan kerja, penyandang disabilitas mmapu membangun hubungan kerja yang baik serta meningkatkan moral dan kesetiaan dalam bekerja.

Manfaat lain dalam mempekerjakan penyandang disabilitas adalah meningkatkan produktivitas tempat kerja, menjadi contoh positif bagi rekan kerja, menyediakan karyawan yang andal, sangat kooperatif, setia, dan sangat efektif. Selain 
itu dapat menambahkan pemikiran kreatif dan keterampilan pemecahan masalah yang lebih baik, meningkatkan kumpulan tenaga kerja dan pekerjaan retensi, mengurangi ketidakhadiran, mempromosikan keragaman tempat kerja, menjadi fakta bahwa industri perhotelan harus dianggap sebagai industri dengan peluang kerja yang layak bagi penyandang disabilitas (Lestari, 2018).

Lebih lanjut, hasil penelitian dari Miethlich dan Oldenburg (2020) menunjukkan bahwa mempekerjakan penyandang disabilitas dapat diklasifikasikan sebagai pekerjaan yang berharga, langka dan mahal untuk ditiru dan jika perusahaan berhasil menggunakan sumber daya ini secara efektif, hal itu mengarah pada keunggulan kompetitif yang berkelanjutan. Selain itu, dampak positif dari memperkerjakan penyandang disabilitas bagi perusahaan adalah dalam hal membangun budaya kerja dalam saling membangun toleransi. Elemen utama dalam ketenagakerjaan proaktif penyandang disabilitas adalah pengurangan hambatan mental dan fisik di dalam perusahaan (Miethlich dan Slahor 2018, Hidegh dan Csillag, 2013; Markel dan Barclay, 2009). Budaya perusahaan yang ramah disabilitas perlu diciptakan untuk mempromosikan ketenagakerjaan penyandang disabilitas. Hal ini dapat dicapai dengan menghilangkan prasangka dan stereotip (Houtenville dan Kalargyrou, 2012, 2014).

Terkait dengan pekerjaan di manajemen perhotelan, ada beberapa tahapan penting yang harus dilakukan dalam tahapan analisis pekerjaan bagi SDM Penyandang disablitas, diantaranya:

1. Menentukan tugas dan peran pekerjaan

2. Menentukan bahaya kerja, kit kerja dan akomodasi dalam kategori yang wajar

3. Menentukan jenis atau tingkat disabilitas pekerja

4. Peraturan hukum dan adanya komunikasi yang baik dari manajemen puncak kepada pekerja dengan penyandang disbailitas. 
Bidang pekerjaan dapat dilakukan baik bagian depan kantor (front office) seperti layanan resepsionis, pelayanan restaurant (food and beverage services), bell boy maupun bagin kantor belakang (back office) seperti house keeping, kitchen, staf administrasi pemasaran maupun keuangan. Hal ini disesuaikan dengan kondisi atau jenis disabilitas dan tanggung jawab kerja yang diberikan.

Groschl (2007), menjelaskan jenis disabilitas dan bentuk reasonable accommodation dalam paparan tabel berikut ini. Reasonable accommodation adalah bentuk modifikasi atau penyesuaian pada pekerjaan, lingkungan kerja, atau cara biasanya dilakukan selama proses perekrutan atau selama melaksanakan pekerjaan sehingga dapat melaksanakan fungsinya dengan baik.

Tabel 1. Jenis disabilitas dan reasonable accommodation.

\begin{tabular}{ll}
\hline Jenis cacat & Reasonable accomodation \\
\hline Low Vision & Akomodasi bagi orang-orang dengan visi rendah termasuk teks \\
rendah) & besar cetak, handout, tanda-tanda, dan label peralatan, \\
& publikasi pengembangan karir, instruksi kerja, atau bahan cetak \\
& lainnya dicatat pada kaset audio. \\
& Contoh lain dari akomodasi untuk penyandang low vision \\
& termasuk menyediakan tempat duduk dengan penerangan \\
& yang cukup; brosur format elektronik, pengumuman pekerjaan, \\
& dan informasi lainnya serta melengkapi komputer dengan \\
& monitor besar dan perangkat lunak pembesar layar. \\
& Bahan cetak yang menggunakan komputer untuk membaca \\
& teks dengan lantang dan / atau menghasilkan Braille. Contoh \\
lain dari akomodasi untuk tunanetra seperti kalkulator & berbicara dan pengatur waktu taktil; dan komputer dengan \\
pembaca karakter optik, keluaran suara, tampilan layar Braille, \\
dan printer Braille.
\end{tabular}




\begin{tabular}{ll}
\hline Jenis cacat & Reasonable accomodation \\
\hline Penyandang & Penyediaan penerjemah, sistem amplifikasi suara, pencatat, alat \\
Tunarungu & bantu visual, dan surat elektronik untuk rapat dan diskusi \\
& kantor. Sistem peringatan visual untuk keadaan darurat \\
& mungkin juga perlu dipasang. \\
\hline Gangguan & Dapat didukung dengan penggunaan tongkat, alat bantu jalan, \\
mobilitas & atau kursi roda, hingga gangguan tubuh bagian atas, yang \\
& dapat mengakibatkan penggunaan tangan secara terbatas atau \\
& tidak sama sekali. Komputer tertentu juga bisa menjadi solusi \\
& yang baik untuk kecacat an ini. \\
\hline Contoh akomodasi untuk individu yang memiliki gangguan \\
kesehatan termasuk penyediaan pencatat dan / atau instruksi \\
kesehatan & yang direkam; persyaratan kehadiran yang fleksibel; tugas \\
& tersedia dalam format elektronik; dan surat elektronik untuk \\
& rapat staf, diskusi kantor, dan distribusi materi dan catatan \\
& lokasi kerja. Telecommuting merupakan suatu pilihan alternatif \\
& bagi orang-orang dengan gangguan kesehatan. \\
\hline Metidakmampuan & Contoh akomodasi untuk orang yang memiliki \\
& ketidem keluaran ucapan berbasis komputer menyediakan suara \\
& alternatif untuk beberapa orang yang tidak dapat berbicara. \\
& Karena surat elektronik tidak membutuhkan kemampuan \\
& visual, aural, dan taktil dimasukkan ke dalam arahan; dan \\
\hline Gangguan Bicara
\end{tabular}




\begin{tabular}{ll}
\hline Jenis cacat & Reasonable accomodation \\
\hline & $\begin{array}{l}\text { komputer dengan keluaran suara dan pemeriksa ejaan dan tata } \\
\text { bahasa. }\end{array}$ \\
\hline $\begin{array}{l}\text { Disabilitas } \\
\text { Psikiatri }\end{array}$ & Untuk disabilitas ini harus ada instruksi yang jelas, pekerjaan \\
\end{tabular}

Sumber: Groschl (2007)

Dalam implementasinya, memperkerjakan kaum disabilitas memberikan tantangan tersendiri ketika memasuki dunia kerja. Seperti yang diungkapkan dari hasil penelitian Junaedi, C Marliana (2003), Hwa, Magdalena Ang Chooi (2005) bahwa dalam konteks budaya masyarakat kita belum dapat memberikan penilaian secara obyektif terhadap perbedaan yang terjadi termasuk dalam memahami keberadaan penyandang disabilitas. Dampak lain dari pandangan diskriminatif ini menyebabkan adanya penghambat dalam aspek peningkatan karir dan upah di lingkungan kerja.

\section{Hasil dan Pembahasan}

\section{Faktor Penyebab belum Optimalnya Penempatan Penyandang Disabilitas}

Berdasarkan hasil beberapa kajian terkait penyebab belum optimalnya penempatan penyandang disabilitas di Indonesia khususnya di sektor pariwisata. Sistem kebijakan kuota bagai penyandang disabilitas di sektor swasta dan pemerintah dalam implementasinya belum dilaksanakan sepenuhnya (Dewi, 2015). Hal ini bisa disebabkan oleh fakor peketja maupun penyedia kerja. Terkadang perusahaan mendapatkan kesulitan akses informasi mengenai data penyandang disabilitas yang membuthkan kerja. Demikin juga sebaliknya pencari kerja tidka mengetahu perushaan mana saja yang menyediakan kesmepatan kerja buat mereka dengan keterbatas yang dimiliki. Sementara itu hasil penelitian Saleh (2018) megindikasikan masih belum berjalannya pemenuhan bagi penyandang cacat studi kasus di Kota Semarang. Dari jumlah 3.990 perusahaan penempatan pentandang disabilitas di 
perusahaan tersebut belum terpenuhi. Hal ini juga trejadi pada penelitian Istifarroh, \& Nugroho (2019); Wardah (2019) walaupun sudah ada kebijakan kuota 1 \% untuk perusahaan swasta dan $2 \%$ untuk perusahaan pemerintah namun hal itu belum dapat diimplementasikan.

Selain itu hasil penelitian yang berbeda telah dilakukan oleh Circle Indonesia (2014) dengan hasil terdapat beberapa perusahaan yang telah memenuhi persentasi dalam memperkerjakan penyandang disabilitas. Studi dilakukan di beberapa perusahaan diantaranya Yogyakarta, Sidoarjo, Jakarta dan Bogor. Untuk di sektor industri pariwisata (Hotel) ditemukan di satu sampel yaitu Shangri-La. Dapat dikatakan bahwa masih sulitnya pemenuhan dalam memperkerjakan disabilitas baik dari sisi karyawan maupun industri penyedia pekerjaan.

Dari hasil penelitian dan wawancara penulis dapat diidentifkasi bahwa faktorfaktor yang menyebabkan belum optimalnya penempatan SDM Penyandang disabilitas adalah:

1. Faktor internal perusahaan dimana perusahaan memiliki keterbatasan informasi mengenai data penyandang disabilitas yang sudah memiliki aspek keterampilan. Keterampilan ini sangat dibutuhkan untuk memenuhi kebutuhan perusahaan.

2. Belum adanya integrasi data yang dimilki baik dari sisi pencari kerja maupun perusahaan penyedia kerja. Demikian juga dengan pihak pemerintah yang memiliki keterbatasan data mengenai kompetensi yang dimiliki oleh penyandang disabilitas. Dengan demikian penyandang disabilitas juga tidak dapat mengakses informasi mengenai lowongan atau kesempatan bekerja.

3. Masih adanya stigma negatif dari perusahaan terhadap kemampuan kinerja penyandang disabilitas, terlebih di sektor pariwisata (hotel industri) yang mengedapankan pelayanan prima (excellent service) kepada setiap tamu. Cara pandang yang sebenarnya belum tentu benar seutuhnya ini juga berdampak 
pada kesmepatan penempatan kepada karyawan atau SDM yang memiliki disabilitas.

4. Adanya cara pandang diskriminasi bahwa SDM penyandang disabilitas memiliki kemampun yang terbatas sehingga mereka dianggap tidak layak untuk di bagian kantor depan (front office). Padahal jika dikaji secara mendalam kemampuan karyawan yang tunarungu atau tunawicara jika mendapatkan pelatihan yang optimal dapat melaksanakan tugasnya dengan baik.

5. Masih kurangnya sarana atau alat pendukung ketika menempatkan penyandang disabilitas untuk menopang kegiatan kerjanya dalam memberikan pelayanan tamu hotel.

6. Adanya pertimbangan bahwa dengan memperkerjakan penyandang disabilitas diperlukan biaya tambahan terutama dalam memberikan pelatihan secara khusus dan penyediaan saran apendukung lainnya.

\section{Peran Stakeholder}

1. Peran Organisasi Internasional

Organisasi perburuhan internsioanal memiliki peranan yang sangat penting dalam memberikan perlindungan baik secara hukum dan moral kepada penyandang disabilitas. Bentuk dukungan ini telah tampak dengan lahirnya konvensi tentang keterampilan dan kesempatan kerja pada tahun 1983. Sementara itu pada tahun 2001, ILO juga menyetujui mengenai pedoman pengelolaan penyandang disbailitas. Namun hingga hari, masih banyak SDM penyandang disabilitas yang belum dapat mengembangkan potensi kerjanya secara optimal.

2. Peran Pemerintah dalam membuat kebijakan

Pemerintah sebagai pembuat kebijakan memiliki peranan dalam memberikan perlindungan terhadap penyandang disabilitas. Adanya pandangan yang masih diskriminatif dari sebagian masyarakat, membuat penyandang disabilitas merasa 
tersisihkan dalam dunia kerja, walaupun pada dasarnya mereka memiliki kemampuan yang tidak kalah dengan pekerja normal. Manfaat lain dari kebijakan pemerintah adalah memberikan perlindungan dalam meningkatkan kemampuan serta pemberdayaan sehingga dapat dapat hidup lebih mandiri.

\section{Peran Asosiasi dan Industri Pariwisata PHRI}

Asosiasi dan industri dapat bekerjasama dalam menyiapkan seperangkat aturan yang implementatif guna mengoptimalkan penyerapan penyandang disabilitas.

\section{Peran Perguruan Tinggi dalam Mengembangkan Kurikulum}

Peran Perguruan tinggi dalam menyiapkan kurikulum berbasis kebutuhan penyandang disabilitas saat ini menjadi penting. Hal ini akan menjemabtani informasi kepada calon pekerja sebelum terjuan ke dunia industri nyata. Selain itu, penyediaan sertifikasi kompetensi khusus bagi penyandang disabilitas dikaitkan di bidang pariwisata (Industri hotel) akan menjadi penguatan baru dna memberikan kepercayaan diri bagi penyandang disabilitas dalam menunjukkan kinerjanya yang profesional dan kompeten. Tentu saja ini disesuaikan dengan kondisi dan jenis disabilitas dimiliki dari setiap pekerja.

Kefungsian dari masing-masing pemangku kepentingan ini menjadi penting dalam upaya penempatan penyandang disabilitas seperti yang disampaikan oleh Groschl (2007) bahwa kesadaran antara semua pemangku kepentingan mulai dari manajemen puncak hingga rekan kerja, upaya hukum, pemerintahan program dan inisiatif yang mempromosikan akses yang sama untuk mereka.

Berdasarkan dari kajian literatur dan wawancara, didapatkan hasil bahwa terdapat beberapa faktor yang menyebabkan mengapa memperkerjakan penyandang disabilitas belum dapat dengan baik diimplementasikan. Hal ini dapat dilihat dari dari dua sisi baik perusahaan maupun pekerja penyandang disabilitas. Dari sisi 
perusahaan, perusahaan belum memiliki data base yang terintegrasi sehingga informais yang dimiliki sangat terbatas mengenai darimana dan bagiamana mereka dapat merekruit tenaga kerja penyandang disbailitas.

Demikian halnya juga dari sisi calon pekerja penyandang disabilitas masih kurangnya memnerima informasi mengenai kesempatan bekerja di perusahaanperusahaan tertentu termasuk di Perhotelan. Faktor lain adalah karena masih adanya stigma negatif terhadap penyandang disabilitas dalam hal kemampun kinerja dan penampilan. Sementara itu kebijkan lintas sektor yang belum terkomunisakan dengan baik misalnya anatara menyingkronkan kebijakan pemerintah dengan industri. Kaitan penempatan dengn bidang perhotelan terdapat divisi- divisi yang dapat diisi baik di aspek front office maupun back office sepanjang mereka mendapatkan pelatihan dan didudukung oleh reasonable accommodation yang memenuhi standar bagi penyandang disbailitas. Dengan demikian diperlukan upaya kerjasama lintas sektor yang melibatkan oragnisasi internasional, pemerintah pusat sebagai pembuat kebijakan, peran serta asosiasi dan industri pariwisata juga perguruan tinggi dalam menyiapkan kurikulum berbasis kebutuhan penyandang disabilitas sehingga akan menjadi jembatan kemudahan saat mereka berasa di dunia kerja.

\section{Kesimpulan dan Saran}

\section{Kesimpulan}

Kondisi fisik yang terbatas bagi penyandang disabilitas tidak dapat dijadikan sebagai penilaian buruk terhadap kinerja. Berdasarkan hasil observasi dan data yang ada tidak sedikit kaum disabilitas yang memiliki keterampilan yang dapat mendukung kinerja perusahaan. Upaya dukungan penyandang disabilitas ini dapat diberikan dengan penyediaan fasilitas pendukung baik secara fisik maupun nonfisik dalam mengembangkan potensi yang dimiliki. Terkait dengan kesempatan bekerja penyandang disabilitas khususnya di industri pariwisata, hal ini dapat dilakukan 
dengan baik sepanjang dilengkapi dengan pemenuhan reasonable accommodation yang disesuaikan dengan jenis disabilitas dan pekerjaan yang dibebankan.

\section{Saran}

Terdapat beberapa saran terkait dengan hasil penelitian ini diantaranya:

1. Pelaksanaan rekruitmen dan seleksi penyandang disabilitas tidak dipandang sebagai bias maupun diskriminasi. Dengan demikian Semua aspek dalam prosedur penempatan kerja harus didasarkan pada kualifikasi, kompetensi, dan pengetahuan kerja dari penyandang disabilitas.

2. Pemerintah dan industri bersinergi untuk membuat suatu regulasi yang implementatif dalam upaya mengoptimalkan penyandang disabilitas untuk pemenuhan haknya sebagai SDM yang dipandai memiliki kompetensi.

3. Pelaksanaan kegiatan latihan dan uji kompetensi dari setiap penyandang disabilitas yang disesusikan dengan jenis disabilitas sehingga mereka tetap memiliki rasa percaya diri saat bekerja.

\section{Ucapan Terima Kasih}

Terima kasih kepada semua pihak yang telah membantu dalam menyelesaikan hasil penelitian ini diantaranya Senior Employment Service Officer, Direktorat Penempatan Tenaga Kerja Dalam Negeri, Kementerian Ketenagakerjaan, Republik Indonesia, Anggota Asosiasi PHRI (Perhimpunan Persatuan Hotel dna Restoran Indonesia), dan Pelaku usaha di bidang Perhotelan.

\section{Daftar Pustaka}

Aji, ALD dan Haryani, TN. Diversitas dalam Dunia Kerja: Peluang dan Tantangan bagi Disabilitas. Spirit Publik Volume 12, Nomor 2. Oktober 2017 (83-93). 
Dewi, U. (2015). Implementasi kebijakan Kuota bagi Penyandang Disabilitas untuk Mendapatkan Pekerjaan di kota Yogyakarta. Natapraja. Jurnal kajian Ilmu Administrasi Negara, Vol.3, (No.2), p81.

Government of Western Australia Department of Communities Disability Services. (n.d). Benefits of employing people with disability. Retrieved from http://www.disability.wa.gov.au/business-and- government1/business-andgovernment/employing-people-with-disability-disability-services commission-disability-wa/benefits-of-employing-people-withdisability/(Diunduh,12 Oktober 2020).

Groschl, S (2007). An exploration of HR policies and practices affecting the integration of persons with disabilities in the hotel industry in major Canadian tourism destinations.Elsevier Hospitality Management :26 666-686.

Hidegh, A. L. and Csillag, S. (2013), 'Toward "mental accessibility": changing the mental obstacles that future Human Resource Management practitioners have about the employment of people with disabilities', Human Resource Development International, 16 (1), 22-39.

Houtenville, A. and Kalargyrou, V. (2012), 'People with Disabilities: Employers' Perspectives on Recruitment Practices, Strategies, and Challenges in Leisure and Hospitality', Cornell Hospitality Quarterly, 53 (1), 40-52.

Houtenville, A. and Kalargyrou, V. (2014), 'Employers' perspectives about employing people with disabilities: A comparative study across industries', Cornell Hospitality Quarterly, 56 (2), 168-179.

Hwa, Magdalene Ang Chooi. Rational Tactics and Work Outcomes: Differential Effects of Disability. International Journal of Social Science and Humanity, Vol 2, No 3, May 2012.

Istifarroh \& Nugroho, Widhi Cahyo. (2019). Perlindungan Hak Disabilitas Mendapatkan Pekerjaan Di Perusahaan Swasta Dan Perusahaan Milik Negara. Mimbar Keadilan, Vol.12, (No.1), p.32.

Junaedi, C. Marliana. Mengelola Diversitas: Penyebab Kegagalan dan Model yang Efektif. Kinerja Volume 7, No 1, Tahun 2003. Hal 22-28.

Kementerian Sosial. (2020). Jumlah Penyandang Cacat di Indonesia. Sumber: ww.kemsos.go.id/jumlah penyandang cacat di Indonesia. Di unduh 10 Oktober 2020.

Lestari (2018), Tourism and Disability: Opportunity of Job Placement of People with disability (PwD) in Hotel sector (Tidak dipublikasikan).

Lindsay,S., Cagliostro, E., Albarico, M., Mortaji, N., \& Karon, L., (2018). A Systematic Review of the Benefits of Hiring People with Disabilities. Journal of Occupational Rehabilitation, Vol.28, (No.4), pp.634-655. 
Markel, K. S. and Barclay, L. A. (2009), 'Addressing the underemployment of persons with disabilities: Recommendations for expanding organizational social responsibility', Employee. Responsibilities and Rights Journal, 21 (4), 305-318.

Miethlich,B. dan Oldenburg (2020). Employment of Person with Disabilities as Competitive Advantage: An Analyisis of the Competitive Implication. Education Excellence and Innovation Management through Vision 2020.

Miethlich, B. and Šlahor, L'. (2018). Employment of persons with disabilities as a corporate social responsibility initiative: Necessity and variants of implementation', Proceedings of the 6th CBU International Conference on Innovations in Science and Education, ISBN: 978-80-270-5037-6, 21-23 March 2018, Prague, Czech Republic, 350-355.

Millmore, et al. (2007). Strategic Human Resource Management. Contemporrary Issues. United Kingdom: Prentice Hal. @Pearson Education Limited.

Pedoman ILO (International Labour Organization). (2013). Tentang Pengelolaan Penyandang Disabilitas Di Tempat Kerja.

Rozali, Norhasyikin., Shuhairimi, Abdullah., Ishak, Siti Intan Diyana., Azmi, Alia Ashrani., \& Akmar, Nurul Husna. (2017). Challenges faced By People with Disability for Getting Jobs: Entrepreneurship Solution for Unemployment. International Journal of Academic Research in Business and Social Science, Vol.7, (No.3), pp.333-339 .

Shaleh, I. (2018). Implementasi Pemenuhan Hak bagi Penyandang Disabilitas Ketenagakerjaan di Semarang. Kanun: Jurnal Ilmu Hukum, Vol.20, (No.1), p.79.

UNITED NATIONS-ESCAP. (2019). Disability at Glance 2019 : Strengthening Employment Prospect for Person with Disabilities in Asia and The Pacific. Retrieved from https:// https://www.unescap.org/publications/disability-glance-2019 (Diunduh 12 Oktober 2020).

Wardah, S. (2019) Pemenuhan Hak Penyandang Disabilitas Dalam Mendapatkan Pekerjaan Di Bumn, Law Reform Program Studi Magister Ilmu Hukum Volume 15, Nomor 2, Fakultas Hukum Universitas Diponegoro (hal. 225-238).

World Travel \&Tourism Council (WTTC), 2016. Sumbangsih Peran Sektor Pariwisata di Dunia. Diunduh 10 Oktober 2020.

Yuniarsih, T. (2018). Kinerja Unggul Sumber Daya Manusia. Bandung: Rizqi Press. 


\section{Profil Penulis}

Titing Kartika, S.Pd.MM.MBA adalah dosen di Sekolah Tinggi Ilmu Ekonomi Pariwisata YAPARI Bandung. Pendidikan S2 ditempuh pada program Dual Degree di Univeristas Sahid Jakarta (Magister Manajemen Pariwisata) tahun 2010 dan di Univeristi Utara Malaysia pada program Magister Business Administration of Tourism and Hospitality Management tahun 2009. Saat ini sedang menyelesaikan Program S3 Doktor Manajemen di Universitas Pendidikan Indonesia. Bidang ketertarikan penelitian adalah Manajemen Pariwisata, Community Based Tourism, Pemasaran Pariwisata.

Prof. Dr. Hj. Tjutju Yuniarsih, S.E., M.Pd.. adalah Dosen di Prodi Pendidikan Manajemen Perkantoran Fakultas Pendidikan Ekonomi dan Bisnis Universitas Pendidikan Indonesia. Bidang keahlian yang diampu adalah Pendidikan Manajemen. Menyelesaikan Pendidikan S2 jurusan Administrasi Pendidikan di IKIP Bandung pada tahun 1989 dan S3 Administrasi Pendidikan di IKIP Bandung pada tahun 1998.

Dr. Hady Siti Hadijah, S.Pd., M.Si, adalah dosen Program Studi Penddikan Manajemen Perkantoran Fakultas Pendidikan Ekonomi dan Bisnis Unversitas Pendidikan Indoneisa. Bidang keahlian yang diampu adalah Manajemen SDM, Manajemen Perkantoran. Ketertarikan bidang penelitian adalah mengenai manajemen SDM. 